\title{
IMPLEMENTASI KEBIJAKAN PROGRAM BEDAH RUMAH DI DINAS PERUMAHAN, PERMUKIMAN DAN PERTANAHAN KABUPATEN POLEWALI MANDAR
}

\author{
Ahmad Isyraq S. ${ }^{1}$ \\ ${ }^{1}$ Prodi Ilmu Pemerintahan, Fakultas Ilmu Sosial dan Ilmu Pemerintahan \\ Universitas Al Asyariah Mandar \\ Email: ahmadisra9751@gmail.com \\ Mahyuddin Ibrahim ${ }^{2}$ \\ 1Prodi Ilmu Pemerintahan, Fakultas Ilmu Sosial dan Ilmu Pemerintahan \\ Universitas Al Asyariah Mandar \\ Email: mahyuddin ibrahim@gmail.com
}

\begin{abstract}
This study aims to determine the implementation of housing renovation program policies at the Housing, Settlement and Land Service of Polewali Mandar Regency. The research method used is descriptive research with a qualitative approach. The results showed that the house renovation program in Polewali Mandar Regency was implemented through the standards and objectives of the Home Improvement Program referring to the Regulation of the Minister of Public Works and Public Housing regarding self-help housing stimulant assistance in 2016 and Regent Regulation number 438 of 2016. The implementation of the Home Improvement Program Policy goes well. It is still necessary to increase the distribution of assistance in each district.
\end{abstract}

\section{ABSTRAK}

Penelitian ini bertujuan untuk mengetahui Implementasi Kebijakan Program Bedah Rumah di Dinas Perumahan, Permukiman dan Pertanahan Kabupaten Polewali Mandar. Metode penelitian yang digunakan adalah penelitian deskriptif dengan pendekatan kualitatif. Hasil penelitian menunjukkan bahwa program bedah rumah di Kabupaten Polewali Mandar dilaksanakan melalui standar dan tujuan pelaksanaan Program Bedah Rumah mengacu kepada Peraturan Menteri Pekerjaan Umum dan Perumahan Rakyat tentang bantuan stimulan perumahan swadaya tahun 2016 dan Peraturan Bupati nomor 438 tahun 2016. Implementasi Kebijakan Program Bedah Rumah sudah berjalan dengan baik. Masih perlu meningkatkan pemerataan pemberian bantuan di tiap Kecamatan.

Kata Kunci: Implementasi, Kebijakan, Bedah Rumah. 


\section{PENDAHULUAN}

Tempat tinggal pada dasarnya merupakan wadah bagi kehidupan manusia atau keluarga dalam melangsungkan kehidupanya. Tanpa tempat tinggal yang layak, manusia tidak akan dapat hidup dengan layak. Salah satu yang menjadi penyebab dari masih banyaknya tempat tinggal yang tidak layak di indonesia adalah karena masih banyaknya masyarakat berpenghasilan rendah . Jumlah masyarakat berpenghasilan rendah di Indonesia saat ini masih cukup besar, yang menyebabkan masih banyak tempat tinggal warga yang masuk kategori rumah tidak layak huni (RTLH). Berdasarkan data dari badan pusat statistik (BPS) pada tahun 2015 mencatat jumlah RTLH di Indonesia sebanyak 2,51 juta unit dengan rincian 2,18 juta rawan layak huni dan 0,33 juta benar-benar tak layak huni. Pekerjaan rumah bagi pemerintah dalam RPJMN 2015-2019 adalah menurunkan jumlah RTLH dari 2,51 juta unit menjadi 1,9 juta unit. Keadaannya mulai dari rusak ringan hingga berat. Untuk daerah daerah di Indonesia jumlah rumah tidak layak huni sebarannya merata di seluruh wilayah Indonesia. Kabupaten Polewali Mandar berdasarkan data dari Dinas Perumahan, Permukiman dan Pertanahan Kabupaten Polewali Mandar jumlah RTLH di Kabupaten Polewali Mandar tahun 2015 yaitu sebanyak 21,618 ribu unit, tahun 2016 yaitu sebanyak 21,301 ribu unit, tahun 2017 yaitu sebanyak 20,758 ribu unit, tahun 2018 yaitu sebanyak 20,083 ribu unit dan tahun 2019 yaitu sebanyak 18.832 ribu unit.

Pemerintah melakukan berbagai cara untuk mengurangi jumlah RTLH di indonesia salah satunya adalah dengan membuat program bedah rumah. Program ini bertujuan, untuk membantu masyarakat kurang mampu. Masyarakat yang mendapatkan program ini adalah masyarakat berpenghasilan rendah yang selanjutnya disingkat MBR. Masyarakat berpenghasilan rendah adalah kelompok masyarakat yang mengalami tekanan ekonomi, sosial, budaya dan politik yang cukup lama dan dapat menimbulkan budaya miskin.

Menurut teori George C. Edwards III dalam implementasi atau pelaksanaan suatu kebijakan dipengaruhi oleh empat variabel, yakni; (1) komunikasi, (2) sumberdaya, (3) disposisi dan, (4) struktur birokrasi. Keempat variabel tersebut menurut George C. Edwards III juga saling berhubungan satu sama lain. Implementasi atau pelaksanaan program bedah rumah di Kabupaten Polewali Mandar dilaksanakan berdasarkan Peraturan Menteri Pekerjaan Umum dan Perumahan Rakyat tentang bantuan stimulan perumahan swadaya tahun 2016 dan Peraturan Bupati nomor 438 tahun 2016 tentang penetapan lokasi perumahan kumuh dan permukiman kumuh kawasan perkotaan Kabupaten Polewali Mandar.

Kementerian PUPR pada tahun 2018 menganggarkan Rp 3,2 triliun untuk pembangunan 180 ribu rumah tidak layak huni bagi masyarakat 
berpenghasilan rendah di seluruh Indonesia. Kabupaten Polewali Mandar pada tahun 2018 diperkirakan mendapatkan kouta program bedah rumah sebanyak 1200 unit yang diperuntukkan bagi masyarakat berpenghasilan rendah (MBR) yang dimana anggaran program bedah rumah ini bersumber dari APBD, APBN maupun bantuan luar negeri yaitu dari bank dunia. Adapun tiga klasifikasi kategori penerima bantuan progran bedah rumah di Kabupaten Polewali Mandar pada tahun 2018 berdasarkan informasi yang di dapatkan dari Dinas Perumahan, Permukiman dan Pertanahan Kabupaten Polewali Mandar yaitu kategori berat menerima bantuan Rp 15 juta, kategori sedang menerima bantuan Rp 10 juta, dan kategori ringan menerima bantuan $\mathrm{Rp} 7,5$ juta.

\section{METODE PENELITIAN}

\section{Jenis Penelitian}

Berdasarkan jenis penelitiannya ini merupakan penelitian deskriptif dengan pendekatan kualitatif, yang mana studi ini memusatkan perhatian pada masalah/ fenomena yang ada pada saat penelitian dilakukan, yang bersifat aktual, yang kemudian digambarkan realita yang jelas dan bertujuan untuk mengetahui secara terperinci Implementasi Kebijakan Program Bedah Rumah di Dinas Perumahan, Permukiman dan Pertanahan Kabupaten Polewali Mandar.

\section{Teknik Pengumpulan Data}

Teknik pengumpulan data adalah teknik atau cara yang dilakukan oleh peneliti untuk menggumpulkan data. Adapun teknik pengumpulan data dilakukan dalam memperoleh informasi dalam rangka mencapai tujuan penelitian yaitu :

a. Wawancara yakni teknik pengumpulan data yang diperlukan mendapatkan keterangan-keterangan lisan melalui komunikasi langsung bertatap muka dengan orang yang dapat memberikan keterangan kepada peneliti terkait informasi yang dibutuhkan dalam penelitian ini. Yang diwawancarai seputar Implementasi Program Bedah Rumah di dinas Perumahan, Permukiman dan Pertanahan Kabupaten Polewali Mandar.

b. Observasi yaitu teknik ini dilakukan dengan cara mengadakan pengamatan langsung dengan objek penelitian guna mendapatkan informasi yang ada hubungannya dengan penelitian.

c. Dokumentasi yaitu ditujukan untuk memperoleh data langsung dari tempat penelitian, yaitu menganalisisi dokumen-dokumen, baik dokumen tertulis, buku-buku relevan, gambar, audio maupun elektronik dan data yang relevan lainnya. 


\section{Teknik Analisis Data}

Teknik analisa data yang digunakan pada penelitian ini adalah analisis kualitatif dimana penulis tidak hanya memberikan penilaian terhadap data yang ada, tetapi akan lebih memprioritaskan kepada gambaran situasi atau secara umum disebut dengan deskriptif analisis. Dari penelitian ini maka data akan dianalisis dengan pelukisan keadaan obyek berdasarkan data obyektif, sehingga data-data yang ada dapat disimpulkan setelah analisis.

\section{HASIL PENELITIAN}

\section{Hasil Penelitian}

Implementasi kebijakan program bedah rumah di Kabupaten Polewali Mandar dilaksanakan oleh Dinas Perumahan, Permukiman dan Pertanahan Kabupaten Polewali Mandar tetapi sebelum membahas tentang bagaimana implementasi atau pelaksanaan kebijakan program bedah rumah terlebih dahulu perlu kita ketahui apa itu program bedah rumah, apa tujuan program bedah rumah di Kabupaten Polewali Mandar, dan tahun berapa pertamakali program bedah rumah dilaksanakan di Kabupaten Polewali Mandar. Adapun nama program, kegiatan, berapa besaran anggaran program bedah rumah pada tahun 2018 dan berapa sasaran dari program bedah rumah pada tahun 2018 dapat dilihat pada tabel dibawah ini :

\section{Tabel}

Nama Program, Kegiatan, Anggaran dan Sasaran Program Bedah Rumah Pada Tahun 2018

\begin{tabular}{|c|l|l|l|l|}
\hline No & \multicolumn{1}{|c|}{ Program } & \multicolumn{1}{|c|}{ Kegiatan } & Anggaran & \multicolumn{1}{|c|}{ Sasaran } \\
\hline 1 & $\begin{array}{l}\text { Pengembangan } \\
\text { Perumahan }\end{array}$ & $\begin{array}{l}\text { Peningkatan Kualitas } \\
\text { Perumahan Swadaya }\end{array}$ & $\begin{array}{l}21,13 \text { Miliar } \\
\text { Rupiah }\end{array}$ & $\begin{array}{l}1,251 \\
\text { RTLH }\end{array}$ \\
\hline
\end{tabular}

Sumber: Dinas Perumahan, Permukiman dan Pertanahan Kabupaten Polewali Mandar.

Program bedah rumah di Kabupaten Polewali Mandar dilaksanakan melalui standar dan tujuan pelaksanaan Program Bedah Rumah atau Bantuan Stimulan Perumahan Swadaya (BSPS) yang mengacu kepada Peraturan Menteri Pekerjaan Umum dan Perumahan Rakyat tentang bantuan stimulan perumahan swadaya tahun 2016 dan Peraturan Bupati nomor 438 tahun 2016 tentang penetapan lokasi perumahan kumuh dan permukiman kumuh kawasan perkotaan Kabupaten Polewali Mandar. Peraturan Menteri ini dimaksudkan sebagai pedoman bagi pemerintah pusat, pemerintah provinsi, pemerintah kabupaten/kota, pemerintah desa, dan masyarakat dalam melaksanakan penyaluran bantuan Bedah Rumah atau Bantuan Stimulan Perumahan 
Swadaya (BSPS). Peraturan Menteri dan Peraturan Bupati ini bertujuan agar penyaluran bantuan dapat dilaksanakan dengan tertib, efisien, ekonomis, efektif, transparan, dan akuntabel. Kemudian sebelum melakukan pembangunan dan penetapan calon penerima bantuan, Dinas Perumahan, Permukiman dan Pertanahan Kabupaten Polewali Manda telah melakukan pendataan keseluruhan Rumah Tidak Layak Huni (RTLH) di Kabupaten Polewali Mandar yang kemudian data inilah yang menjadi acuan pemerintah dalam menetapkan sasaran Bantuan program Bedah Rumah atau Bantuan Stimulan Perumahan Swadaya (BSPS) di Kabupaten Polewali Mandar. Verifikasi berperan penting dalam ketepatan sasaran program perumahan ini. Adapun data rumah tidak layak huni di Kabupaten Polewali Mandar dapat dilihat pada tabel dibawah ini yaitu sebagai berikut :

Tabel

Data Rumah Tidak Layak Huni

Di Kabupaten Polewali Mandar Tahun 2015-2019

\begin{tabular}{|c|c|c|c|c|c|c|}
\hline \multirow{2}{*}{ No } & \multirow{2}{*}{ Kecamatan } & \multicolumn{5}{|c|}{ Jumlah RTLH Di Kabupaten Polewali Mandar Di } \\
\cline { 3 - 7 } & & $\mathbf{2 0 1 5}$ & $\mathbf{2 0 1 6}$ & $\mathbf{2 0 1 7}$ & $\mathbf{2 0 1 8}$ & $\mathbf{2 0 1 9}$ \\
\hline 1 & Binuang & 1.110 & 1.110 & 1.110 & 1.058 & 908 \\
\hline 2 & Polewali & 1.070 & 1.070 & 978 & 687 & 476 \\
\hline 3 & Matakali & 1.021 & 1.021 & 1.021 & 958 & 898 \\
\hline 4 & Wonomulyo & 1.677 & 1.677 & 1.677 & 1.677 & 1.517 \\
\hline 5 & Tapango & 587 & 587 & 587 & 587 & 527 \\
\hline 6 & Mapilli & 1.138 & 1.138 & 1.138 & 1.085 & 985 \\
\hline 7 & Luyo & 1.826 & 1.826 & 1.826 & 1.767 & 1.767 \\
\hline 8 & Campalagian & 1.387 & 1.387 & 1.387 & 1.282 & 1.232 \\
\hline 9 & Balanipa & 1.594 & 1.594 & 1.256 & 1.256 & 1.256 \\
\hline 10 & Tinambung & 2.175 & 1.858 & 1.745 & 1.693 & 1.413 \\
\hline 11 & Limboro & 1.250 & 1.250 & 1.250 & 1.250 & 1.190 \\
\hline 12 & Alu & 2.064 & 2.064 & 2.064 & 2.064 & 1.944 \\
\hline 13 & Tutar & 1.535 & 1.535 & 1.535 & 1.535 & 1.535 \\
\hline 14 & Anreapi & 786 & 786 & 786 & 786 & 786 \\
\hline 15 & Bulo & 1.187 & 1.187 & 1.187 & 1.187 & 1.187 \\
\hline 16 & Matangnga & 1.211 & 1.211 & 1.211 & 1.211 & 1.211 \\
\hline & Jumlah & 21.618 & 21.301 & 20.758 & 20.083 & 18.832 \\
\hline & & & & & & \\
\hline
\end{tabular}

Sumber : Dinas Perumahan, Permukiman dan Pertanahan Kabupaten Polewali Mandar.

Berdasarkan tabel di atas, jumlah Rumah Tidak Layak Huni (RTLH) di Kabupaten Polewali Mandar terbesar pada tahun 2019 ini tedapat pada 
Kecamatan Alu, disusul oleh Kecamatan Luyo, dan Kecamatan Wonomulyo. Sedangkan jumlah terkecil Rumah Tidak Layak Huni (RTLH) tahun 2019 ini di Kabupaten Polewali Mandar berada di Kecamatan Polewali dan Kecamatan Tapango. Hal tersebut menunjukkan bahwa rumah tidak layak huni tersebar di setiap kecamatan yang ada di Kabupaten Polewali Mandar tetapi dari jumlah total Rumah Tidak Layak Huni (RTLH) di Kabupaten Polewali Mandar mulai dari tahun 2015 yang awalnya berjumlah 21.618 ribu unit pada tahun 2019 mengalami penurunan jumlah RTLH yang kini tinggal 18.832 ribu unit atau berkurang 3.000 ribu unit lebih.

Setiap program pemerintah baik itu yang ditingkat pusat maupun tingkat daerah pasti memiliki anggaran untuk dapat menyukseskan suatu program pemerintah tersebut yang biasanya berasal dari APBD ataupun APBN termasuk juga program bedah rumah yang di ketahui memiliki anggaran yang berasal dari APBD dan APBN. Untuk

Pelaksanaan program bedah rumah dapat dikatakan sukses di Kabupaten Polewali Mandar apabila program bedah rumah itu terlaksana di 16 Kecamatan yang ada di Kabupaten Polewali Mandar. Adapun data realisasi program bedah rumah atau bantuan stimulan perumahan swadaya (BSPS) di Kabupaten Polewali Mandar mulai tahun 2012 sampai tahun 2018 dapat dilihat pada tabel dibawah ini yaitu sebagai berikut :

Tabel

Data Rumah Tidak Layak Huni

Di Kabupaten Polewali Mandar Tahun 2015-2019

\begin{tabular}{|c|l|c|c|c|c|c|c|c|c|}
\hline \multirow{2}{*}{ No } & \multirow{2}{*}{ Kecamatan } & \multicolumn{9}{|c|}{ Tahun } & \multirow{2}{*}{ JML } \\
\cline { 3 - 11 } & & $\mathbf{2 0 1 2}$ & $\mathbf{2 0 1 3}$ & $\mathbf{2 0 1 4}$ & $\mathbf{2 0 1 5}$ & $\mathbf{2 0 1 6}$ & $\mathbf{2 0 1 7}$ & $\mathbf{2 0 1 8}$ & \\
\hline 1 & Binuang & 0 & 150 & 0 & 0 & 0 & 52 & 150 & $\mathbf{3 5 2}$ \\
\hline 2 & Polewali & 66 & 0 & 0 & 0 & 92 & 291 & 211 & $\mathbf{6 6 0}$ \\
\hline 3 & Matakali & 0 & 0 & 0 & 0 & 0 & 63 & 60 & 123 \\
\hline 4 & Wonomulyo & 38 & 0 & 0 & 0 & 0 & 0 & 160 & 198 \\
\hline 5 & Tapango & 0 & 0 & 0 & 0 & 0 & 0 & 60 & $\mathbf{6 0}$ \\
\hline 6 & Mapilli & 0 & 0 & 0 & 0 & 0 & 53 & 100 & $\mathbf{1 5 3}$ \\
\hline 7 & Luyo & 0 & 0 & 0 & 0 & 0 & 59 & 0 & $\mathbf{5 9}$ \\
\hline 8 & Campalagian & 68 & 582 & 543 & 0 & 0 & 105 & 50 & $\mathbf{1 . 3 4 8}$ \\
\hline 9 & Balanipa & 421 & 50 & 0 & 0 & 338 & 0 & 0 & $\mathbf{8 0 9}$ \\
\hline 10 & Tinambung & 284 & 50 & 0 & 317 & 113 & 52 & 280 & $\mathbf{1 . 0 9 0}$ \\
\hline 11 & Limboro & 207 & 0 & 0 & 0 & 0 & 0 & 60 & $\mathbf{2 6 7}$ \\
\hline 12 & Alu & 47 & 0 & 0 & 0 & 0 & 0 & 120 & $\mathbf{1 6 7}$ \\
\hline 13 & Tutar & 0 & 0 & 0 & 0 & 0 & 0 & 0 & $\mathbf{0}$ \\
\hline 14 & Anreapi & 0 & 0 & 0 & 0 & 0 & 0 & 0 & $\mathbf{0}$ \\
\hline
\end{tabular}


Implementasi Kebijakan Program Bedah Rumah di Dinas Perumahan, Permukiman dan Pertanahan Kabupaten Polewali Mandar

\begin{tabular}{|l|l|c|c|c|c|c|c|c|c|}
\hline 15 & Bulo & 0 & 0 & 0 & 0 & 0 & 0 & 0 & 0 \\
\hline 16 & Matangnga & 0 & 0 & 0 & 0 & 0 & 0 & 0 & 0 \\
\hline & Jumlah & $\mathbf{1 . 1 3 1}$ & $\mathbf{8 3 2}$ & $\mathbf{5 4 3}$ & $\mathbf{3 1 7}$ & $\mathbf{5 4 3}$ & $\mathbf{6 7 5}$ & $\mathbf{1 . 2 5 1}$ & $\mathbf{5 . 2 8 6}$ \\
\hline
\end{tabular}

Sumber : Dinas Perumahan, Permukiman dan Pertanahan Kabupaten Polewali Mandar.

Berdasarkan tabel diatas, dapat disimpulkan bahwa realisasi atau pelaksanaan program bedah rumah dari tahun 2012 sampai tahun 2018 terbesar dilaksanakan di Kecamatan Campalagian dan Kecamatan Tinambung dan realisasi terkecil atau tidak mendapatkan bantuan program bedah rumah dari tahun 2012 sampai tahun 2018 yaitu di Kecamatan Tutar, Anreapi, Bulo dan Matangnga.

Dinas Perumahan, Permukiman dan Pertanahan Kabupaten Polewali Mandar hanya mengelola anggaran yang berasal dari dana alokasi khusus (DAK) yang dimana anggaran ini berasal dari Kementerian PUPR sedangkan anggaran program bedah rumah yang berasal dari anggaran Reguler dikelolah oleh Satker Provinsi dan anggaran bsps strategis di kelolah oleh Satker Pusat dan Dinas Perumahan, Permukiman dan Pertanahan Kabupaten Polewali Mandar disini hanya bertindak sebagai pengawas pelaksanaan program bedah rumah yang ada di Kabupaten Polewali Mandar. Masyarakat berpenghasilan rendah yang mendapatkan bantuan program bedah rumah pada tahun 2018 dari anggaran dana alokasi khusus (DAK) yang mana program bedah rumah ini di laksanakan di 1 Desa, 9 Kelurahan di 3 Kecamatan yang ada di Kabupaten Polewali Mandar.

Teori yang digunakan dalam menganalisis implementasi kebijakan tentang program bedah rumah di Dinas Perumahan, Permukiman dan Pertanahan Kabupaten Polewali Mandar adalah teori yang dikemukakan oleh George C. Edwards III. Dimana implementasi dapat dimulai dari kondisi abstrak dan sebuah pertanyaan tentang apakah syarat agar implementasi kebijakan dapat berhasil, menurut George C. Edwards III ada empat variabel dalam kebijakan publik yaitu Komunikasi (Communications), Sumber Daya (resources), sikap (dispositions atau attitudes) dan struktur birokrasi (bureucratic structure). Keempat faktor di atas harus dilaksanakan secara simultan karena antara satu dengan yang lainnya memiliki hubungan yang erat. Adapun faktor -faktor yang berpengaruh dalam implementasi menurut George C. Edwards III sebagai berikut :

\section{Komunikasi}

Komunikasi merupakan hal yang sangat penting dalam mencapai tujuan kebijakan publik. Komunikasi merupakan sarana untuk menyeberluaskan informasi, baik dari atas kebawah maupun dari bawah keatas. Implementasi 
yang efektif adalah ketika mereka para pembuat keputusan harus mengetahui apa yang harus mereka lakukan, untuk itu sangat diperlukan komunikasi yang baik. Terdapat tiga komponen untuk mengukur keberhasilan komunikasi, yaitu transmisi, kejelasan dan konsistensi. Dalam hal ini komunikasi harus disalurkan dengan baik, jelas dan konsisten atau tidak berubah-ubah agar menghasilkan suatu implementasi yang baik, tidak membingungkan oleh para pelaksana dan efektif.

a. Transmisi,

Faktor utama dalam komunikasi kebijakan adalah transmisi. Dalam hal ini komunikasi harus disalurkan dengan baik agar menghasilkan suatu implementasi yang baik. Namun dalam pelaksanaanya, transmisi tidak selalu berjalan dengan baik. Seringkali kebijakan tersebut diabaikan atau kesalahpahaman.

Komunikasi dalam program bedah rumah di Kabupaten Polewali Mandar dilaksanakan melalui sosialisasi ditingkat Kelurahan dan Desa di semua Kecamatan yang ada di Kabupaten Polewali Mandar. Dalam sosialisasi tersebut juga dibahas mengenai usulan-usulan RTLH yang ingin diberikan bantuan program bedah rumah dan juga dibahas mengenai persyaratan agar dapat menjadi penerima bantuan program bedah rumah.

b. Kejelasan

Dalam hal ini informasi mengenai keputusan harus diterima dengan jelas dan tidak membingungkan oleh para pelaksana. Seringkali instruksi-instruksi yang diteruskan kepada pelaksana tidak jelas dan tidak menetapkan kapan dan bagaimana program dilaksanakan. Ketidakjelasan pesan komunikasi yang disampaikanberkenaan dengan implementasi kebijakan akan mendorong terjadinya interpretasi yang salah bahkan mungkin bertentangan dengan pesan awal. Edward mengidentifikasikan enam faktor yang mendorong ketidakjelasan implementasi kebijakan. Faktor-faktor tersebut adalah kompleksitas kebijakan publik, keinginan untuk tidak mengganggu kelompok-kelompok masyarakat, kurangnya konsesus mengenai tujuan-tujuan kebijakan, masalah-masalah dalam memulai suatu kebijakan baru, menghindari pertanggungjawaban kewajiban, dan sifat pembentukan kebijakan pengadilan.

Kejelasan program bedah rumah di Kabupaten Polewali Mandar sudah sangat jelas karena program bedah rumah ini memiliki petunjuk yaitu Peraturan Menteri Pekerjaan Umum dan Perumahan Rakyat tentang bantuan stimulan perumahan swadaya tahun 2016 dan Peraturan Bupati nomor 438 tahun 2016 tentang penetapan lokasi perumahan kumuh dan permukiman kumuh kawasan perkotaan Kabupaten Polewali Mandar. 


\section{c. Konsistensi}

Untuk melasanakan implementasi yang efektif maka perintah yang diberikan dalam pelaksanaan suatu komunikasi harus konsisten atau tudak berubah-ubah. Perintah-perintah implementasi yang tidak konsisten akan mendorong para pelaksana mengambil tindakan yang sangat longgar dalam menafsirkan dan mengimplementasikan kebijakan. Jika hal ini terjadi, maka implementasi kebijakan berlangsung tidak efektif.

Konsistensi program bedah rumah di Kabupaten Polewali Mandar sudah sangat jelas karena program bedah rumah ini sudah dilaksanakan berdasarkan petunjuk dari Kementerian Pekerjaan Umum dan Perumahan Rakyat. Salah satu bentuk konsistensi dalam pelaksanaan program bedah rumah adalah apabila tingkat kepuasan dari masyarakat yang menjadi sasaran program dari pemerintah tersebut sudah sangat puas termasuk juga dengan program bedah rumah dimana masyarakat penerima bantuan program bedah rumah pada tahun 2018 dimana dominan masyarakat sudah sangat puas dalam pelaksanaan program bedah rumah ini hal ini juga dapat membuktikan bahwa apakah komunikasi secara konsisten yang dilakukan oleh Dinas Perumahan, Permukiman dan Pertanahan Kabupaten Polewali Mandar.

\section{Sumberdaya.}

Perintah-perintah implementasi selain harus dijalankan dengan cermat, jelas dan konsisten juga diperlukan sumber daya agar implementasi berjalan dengan efektif. Sumber daya yang dimaksud disini yaitu:

\section{a. Staf}

Dalam melaksanakan kebijakan staf dituntut untuk memiliki kemampuan yang memadai, kebijakan akan berhasil apabila staf mampu melaksanakan kebijakan tersebut begitupun sebaliknya kebijakan tersebut akan gagal apabila staf tidak mampu melaksanakan kebijakan. Ada satu hal yang perlu diketahui bahwa jumlah staf tidak selalu memiliki efek positif bagi implementasi kebijakan. Hal ini disebabkan karena kurangnya kecakapan yang dimiliki oleh para pegawai pemerintah ataupun staf, namun disisi lain kurangnya staf juga akan menimbulkan persoalan yang pelik menyangkut implementasi kebijakan yang efektif. Jumlah staf atau pegawai di Dinas Perumahan, Permukiman dan Pertanahan Kabupaten Polewali Mandar berdasarkan Peraturan Daerah Nomor : 12 tahun 2016, maka jumlah SDM atau dalam hal ini jumlah pegawai mulai Tahun Anggaran 2017 tercatat berjumlah 29 orang terbagi atas 14 orang laki-laki dan 15 orang perempuan jumlah ini terbilang sedikit dan juga dapat menghambat setiap pelaksanaan program yang 
ada di Dinas Perumahan, Permukiman dan Pertanahan Kabupaten Polewali Mandar termasuk juga program bedah rumah.

\section{b. Informasi}

Dalam hal ini informasi terbagi menjadi dua yaitu pertama mengenai pelaksanaan kebijakan. Pelaksana kebijakan perlu mengetahui apa yang dilakukan dan bagaimana mereka melakukannya. Dengan demikian, para pelaksana kebijakan harus diberi petunjuk untuk melaksanakan kebijakan. Kedua mengenai ketaatan personil-personil lain terhadap peraturan-peraturan pemerintah. Pelaksana harus mengetahui apakah orang lain yang terlibat dalam pelaksanaan kebijakan menaati undang-undang atau tidak. Informasi mengenai program-program adalah penting terutama bagi kebijakan-kebijakan baru atau kebijakan-kebijakan yang melibatkan persoalan-persoalan teknis.

Informasi mengenai pelaksanaan kebijakan program bedah rumah di Dinas Perumahan, Permukiman dan Pertanahan Kabupaten Polewali Mandar terbilang sangat terbuka bagi masyarakat yang ingin mengetahui tentang program bedah rumah di Kabupaten Polewali Mandar dan mengenai ketaatan personil-personil lain terhadap peraturan-peraturan pemerintah di Dinas Perumahan, Permukiman dan Pertanahan Kabupaten Polewali Mandar terbilang sangat taat.

\section{c. Wewenang}

Kewenangan merupakan hak otoritas yang dimiliki para pelaksana dalam melaksanakan kebijakan yang ditetapkan secara politik. Pada umumnya wewenang harus bersifat formal agar perintah dapat dilaksanakan. Wewenang akan berbeda-beda dari satu program ke program lain serta memiliki banyak bentuk yang berbeda misalnya, hak untuk mengeluarkan surat panggilan untu datang kepengadilan, mengeluarkan perintah pada pejabat lain, menarik dan mnyediakan dana dari suatu program dan lain sebagainya. Kurangnya wewenang yang efektif disadari oleh para pejabat dan karena itu mereka membutuhkan kerjasama dengan pelaksana-pelaksana lain agar implementasi lebih efektif.

Wewenang para pelaksana program bedah rumah dalam hal ini Dinas Perumahan, Permukiman dan Pertanahan Kabupaten Polewali Mandar diatur oleh Peraturan Menteri Pekerjaan Umum dan Perumahan Rakyat tentang bantuan stimulan perumahan swadaya tahun 2016 dan Peraturan Bupati nomor 438 tahun 2016 tentang penetapan lokasi perumahan kumuh dan permukiman kumuh kawasan perkotaan Kabupaten Polewali Mandar secara keseluruhan Dinas Perumahan, Permukiman dan Pertanahan Kabupaten Polewali Mandar sudah menjalankan dengan baik wewenang sesuai dengan instruksi dari Kementerian Pekerjaan Umum dan Perumahan Rakyat. 
d. Fasilitas

Dalam hal ini sarana dan prasarana sangat diperlukan demi keberhasilan suatu kebijakan. Seorang pelaksana yang baik selain memiliki straf yang memadai, memahami apa yang harus dilakukan dan memiliki wewenang untuk melakukan tugasnya juga sebaiknya memiliki fasilitas seperti bangunan kantor untuk melakukan koordinasi serta perlengkapan dan perbekalan lainya yang mendukung proses implementasi tersebut.

Seorang pelaksana yang baik selain memiliki staf yang memadai, memahami apa yang harus dilakukan dan memiliki wewenang untuk melakukan tugasnya juga sebaiknya memiliki fasilitas seperti bangunan kantor untuk melakukan koordinasi serta perlengkapan dan perbekalan lainya yang mendukung proses implementasi tersebut. Fasilitas sarana dan prasarana penunjang pelaksanaan program bedah rumah di Dinas Perumahan, Permukiman dan Pertanahan Kabupaten Polewali Mandar terbilang sangat memadai.

\section{Disposisi}

Kecakapan saja tidak mencukupi tanpa ketersediaan dan komitmen untuk melaksanakan kebijakan tersebut. Edward III mengatakan bahwa "kecenderungan-kecenderungan atau disposisi merupakan salah satu factor yang mempunyai konsekuensi penting bagi implementasi kebijakan yang efektif". Apabila pelaksana bersikap baik atau adanya dukungan terhadap suatu kebijakan tertentu, kemungkinan besar mereka melaksanakan sebagaimana yang diinginkan oleh pembuat keputusan. Begitu juga berlaku sebaliknya apabila terjadi hal yang berlawanan. Disposisi atau sikap pelaksana dalam pelaksanaan program bedah rumah di Dinas Perumahan, Permukiman dan Pertanahan Kabupaten Polewali Mandar terbilang sangat baik dan berkomitmen untuk kesuksesan pelaksanaan program bedah rumah di Kabupaten Polewali Mandar.

Salah satu bukti bahwa Dinas Perumahan, Permukiman dan Pertanahan Kabupaten Polewali Mandar sudah sangat baik dan berkomitmen dalam pelaksanaan program bedah rumah di Kabupaten Polewali Mandar itu terbukti dengan rumah tidak layak huni atau RTLH yang mulai menurun dari yang awalnya pada tahun 2015 berjumlah 21.618 ribu unit pada tahun 2019 mengalami penurunan jumlah RTLH yang kini tinggal 18.832 ribu unit atau berkurang 3.000 ribu unit lebih ini menandakan bahwa sikap pelaksana program bedah rumah sudah terbilang cukup baik dan efektif dalam mengurangi RTLH di Kabupaten Polewali Mandar. 


\section{Struktur birokrasi}

Struktur birokrasi dalam pelaksanakan kebijakan juga mempunyai pengaruh penting. Birokrasi merupakan salah satu badan yang paling sering bahkan secara keseluruhan menjadi pelaksana kebijakan. Birokrasi baik secara sadar atau tidak sadar memilih bentuk-bentuk organisasi untuk kesepakatan kolektif dalam rangka memecahkan masalah-masalah sosial dalam kehidupan modern. Struktur birokrasi yang dimaksud dalam hal ini tidak hanya struktur pemeritah tetapi juga struktur organisasi swasta yang lain.

Dalam hal ini terdapat dua aspek yang mempengaruhi struktur birokrasi. Pertama yaitu mekanisme dan kedua struktur birokrasi itu sendiri. Mekanisme berkaitan dengan Standar Operating Prosedures (SOP).

Struktur birokrasi dalam pelaksanaan kebijakan program bedah rumah meliputi Standar Operasional Prosedur (SOP). SOP program bedah rumah di Dinas Perumahan, Permukiman dan Pertanahan Kabupaten Polewali Mandar pada tahun 2018 dapat dilihat pada Peraturan Menteri Pekerjaan Umum dan Perumahan Rakyat nomor 7/PRT/M/2018 tentang bantuan stimulan perumahan swadaya tahun 2018. SOP inilah yang menjadi acuan dan panduan untuk seluruh pelaksanaan program bedah rumah di Kabupaten Polewali Mandar.

\section{KESIMPULAN}

Implementasi Kebijakan Program Bedah Rumah di Dinas Perumahan, Permukian dan Pertanahan Kabupaten Polewali Mandar sudah berjalan dengan baik apabila dilihat penerima program merupakan masyarakat berpenghasilan rendah yang tidak mampu untuk membangun tempat tinggal yang layak. Walaupun dalam pelaksanaannya, masih ada bebarapa permasalahan yang ditemukan seperti tidak adanya data pasti rumah layak huni di Kabupaten Polewali Mandar, adanya beberapa kecamatan yang belum sama sekali menerima bantuan program bedah rumah mulai dari tahun 2012 sampai tahun 2018 yaitu di Kecamatan Tutar, Anreapi, Bulo dan Matangnga, masih kurangnya sosialisasi oleh Dinas Perumahan, Permukiman dan Pertanahan Kabupaten Polewali Mandar mengenai syarat penting yang harus dipenuhi bagi masyarakat yang ingin mendapatkan bantuan program bedah rumah salah satunya yaitu mengenai upah tukang yang harus disiapkan sendiri oleh masyarakat yang ingin menjadi penerima bantuan program bedah rumah. Namun permasalahan dana tidak ada dikarenakan penerima bantuan program bedah rumah langsung mendapatkan dana dan langsung dijadikan bahan bangunan, tetapi kendala yang dihadapi oleh Dinas Perumahan, Permukiman dan Pertanahan Kabupaten Polewali Mandar adalah adanya beberapa masyarakat penerima bantuan yang tidak menyiapkan upah tukang dari jauh- 
jauh hari. Namun apabila dilihat dari keseluruhan, Implementasi Kebijakan Program Bedah Rumah di Dinas Perumahan, Permukiman dan Pertanahan Kabupaten Polewali Mandar bisa dikatakan sudah berjalan dengan baik dan sesuai standar operasional prosedur atau SOP yang ada.

\section{SARAN}

Artikel ini tentunya terlalu singkat untuk menjelaskan banyak hal ttentang Implementasi Kebijakan Program Bedah Rumah di Dinas Perumahan, Permukiman dan Pertanahan Kabupaten Polewali Mandar. Masih banyak aspek yang perlu dieksplorasi lebih dalam untuk memperoleh gambaran konfrehensif tentang Implementasi Kebijakan Program Bedah Rumah di Dinas Perumahan, Permukiman dan Pertanahan Kabupaten Polewali Mandar.

\section{DAFTAR PUSTAKA}

Andreas Mulyono. (10 Februari 2015). Bedah Rumah. Dipetik pada 28 Oktober 2018, dari Pusat Pengembangan dan Pemberdayaan Pendidikan dan Tenaga Kependidikan Bidang Otomotif Elektronik Malang: http://www.vedcmalang.com/pppptkboemlg/index.php/menuutama/depa rtemen-bangunan-30/1329-pembangunan-rumah-layak-huni.

Efendi Pakpahan. (10 Januari 2017). Faktor Yang Mempengaruhi Implementasi Kebijakan. Dipetik pada 25 Oktober 2018, dari Kumpulan Karya Tulis Ilmiah: http://tugasakhiramik.blogspot.com/2017/01/faktor-yang mempengaruhi-implementasi.html.

Fiki Ariyanti. (18 April 2016). Bedah Rumah Rakyat, Berapa Anggaran dari Pemerintah?. Dipetik pada 28 Oktober 2018, dari Liputan 6: https://www.liputan6.com/bisnis/read/2485876/bedah-rumah-rakyat berapa-anggaran-dari-pemerintah.

Peraturan Menteri Pekerjaan Umum dan Perumahan Rakyat Republik Indonesia Nomor 13/PRT/M/2016 Tentang Bantuan Stimulan Perumahan Swadaya. JDIH Kementerian PUPR.

Radarsulbar.co.id. (6 Mei 2017). Rp 4,1 M untuk Program Bedah Rumah. Dipetik pada 28 Oktober 2018, dari Radar Sulbar: https://radarsulbar.fajar.co.id/2017/05/06/rp-41-m-untuk-program-bedahrumah/.

Z Ramadhana. (19 Mei 2018). Program Bedah Rumah BSPS Disoal, Pilih Kasih, Rutin Didata Tak Pernah Dibedah!. Dipetik pada 28 Oktober 2018, dari Polewali Terkini. Net: http://www.polewaliterkini.net/ 2018/05/program-bedah-rumah-bsps-disoal-pilih.html. 
Z Ramadhana. (04 Juni 2018). Program BSPS Polman, 450 RTLH Dapat Bedah Rumah Rata Rusak Berat. Dipetik pada 28 Oktober 2018, dari Polewali Terkini. Net: http://www.polewaliterkini.net/2018/06/programbsps-polman-450-rtlh-dapat.html.

Zulkarnain. (10 Oktober 2016). Implementasi Kebijakan Bantuan Stimulan Perumahan Swadaya Di Kecamatan Parigi Selatan. Dipetik pada 30 Oktober 2018, dari Jurnal Katalogis, Volume 4. 